\title{
The Comparison of the Interaction of Regional Industrial Clusters with the Financial Sector of the Economy
}

\author{
Grigoryan K.A. ${ }^{a}$ \\ Ramazanov A.V. ${ }^{b}$
}

a,b Kazan Federal University, Institute of Management, Economics and Finance, Kazan, 420008, Russia

Email: rav83@mail.ru

Doi:10.5901/mjss.2015.v6n1s3p256

\section{Abstract}

This article presents a comparative analysis of forms of interaction between real and financial sectors of the economy in different clusters in the regional economy. Significant differences between the nature of the interaction of real and financial sector, depending on the direction of the regional cluster is its orientation to the internal or external customer, as well as the nature of competition and pricing for the products.

Keywords: The region, the industrial cluster, the financial market, the integration of industrial and financial capital, sources of financing of investment programs of the regional cluster.

\section{Introduction}

The problem of interaction between real and financial sectors of the economy has always attracted the attention of economists in modern terms its importance increases even more.

Great attention of scientists and practitioners attract the interaction and integration of manufacturing companies and financial institutions.

A number of publications $[1 ; 2 ; 3 ; 4]$ is devoted to particular aspects of the problem: practical aspects of functioning of the securities market, the formation and implementation of the credit potential of banks, the characterization of monetary policy and other.

These sources thoroughly characterize different forms of integration of industrial and banking capital, but cannot be considered as a comprehensive theoretical and methodological study of its content and role in the modern Russian economy. Not taken into account regional and sectoral factors that determine the motivation of the participants of the financial market and management of industrial companies in the development of relations and cooperation.

The work discusses the process of integrating real and financial sector on the basis of cluster approach. Compares the factors and conditions of interaction between industrial enterprises, participants of the stock market and the banking sector.

\section{Method}

In this article are based on research findings that revealed a tendency of relationship banking capital and industrial enterprises [5]. In General, for the Russian economy were identified two options for the institutional integration of the banking and industrial capital - with the leading role of the subjects of banking and real sectors of the economy.

Study of the Russian and foreign experience of functioning capital market confirm the emergence of new prerequisites of the banking and industrial integration in connection with the transition to a qualitatively different level of globalization and internationalization of the economy [6; 7].

In this article, apply the cluster approach to the analysis of forms and activity relationship of the real and financial sectors discussed feature of this interaction, depending on the characteristics of regional industrial cluster - orientation of trade relations, the level of competition and the characteristics of the pricing.

In the last decade, the study of the principles and mechanism of functioning of territorial clusters is one of the most important and popular areas of economic research worldwide.

The researchers of this problem under the economic cluster understand the concentration of similar, coherent or 
complementary companies, which are characterized by active engagement, transactions and are in dialogue, the search for solutions to common problems.

They share a common infrastructure, labor markets and services, [8] including companies in the cluster have the same access and use the products and services of the financial market. As a result, the cluster contributes to the economic growth of each participant and the region as a whole.

From the point of view of interaction with the banking sector, we can say that the company is included in the cluster, is the preferred client for the Bank, because the benefits from growth expectations and the stability of the cluster. However, the picture is reversed in the event of an economic downturn and deterioration territorial cluster.

It is possible for the following reasons:

1) clusters increase productivity due to access to resources, information, and institutions,

2) clusters increase the share of innovative products, due to internal competition,

3) clusters accelerate the production process, attracting new firms and institutions,

4) clusters make it more understandable and predictable business environment in the area, which contributes to improving the quality of regional strategic planning.

This is an ongoing discussion about how to identify and determine the extent of formation and boundaries of the cluster. This is the starting point of the analysis factors in the development of the cluster, including analysis of the causes and characteristics of the interaction of industrial clusters with the institutions of the financial sector.

Many scholars have promoted the idea of diversification of methods of identification of the cluster, depending on the level of analysis - national level, sectoral level and regional level $[8,9,10]$.

In these works there are two groups of methods:

- qualitative methods

- quantitative methods

Among the quantitative methods of identification of the cluster can be distinguished:

- the coefficient of localization (localization coefficients - LQ),

- analysis of supply chains (input-output analysis),

- dynamic structural analysis (shift-share analysis),

- Giniho coefficient of localization,

- Ellison and Glaeser index of agglomeration,

- Maurel-Sédillot index.

- The most well-known qualitative methods can be attributed

- Expert survey and management companies (interviews with experts and management of the firms),

- Questioning (researches question-forms),

- Situational analysis (case studies).

Localization coefficients compare the characteristics of branches (number of employees, sales and added value) at the regional and national level. The results of the LQ show the dominant localization of enterprises in the given branches [8]. The localization quotients for the number of employees is defined as follows

$\mathrm{LQi}=(\mathrm{zi} / \mathrm{z}) /(\mathrm{Zi} / \mathrm{Z})(1)$

where:

- LQi is localization coefficient of the i-th branch (employees),

- zi is the number of employees of the i-th branch in a region,

- $z$ is the total number of employees in the region,

- $Z i$ is the number of employees of the $\mathrm{i}$-th branch in country,

- $Z$ is the total number of employees in country.

LQiv = (vi/v) / (Vi/V) (2)

where:

- LQiv is localization coefficient of the i-th branch (turnover, value added)

- vi is the value of output (turnover, value added) of the $i$-th branch in a region,

- $v$ is the value of output in the region,

- Vi is the value of output (turnover, value added) of the $i-$ th branch in country,

- $V$ is the value of output in country.

The focus of attention, for the purposes of the study, based on the above methods were selected two industrial cluster in the region of Tatarstan, Russian Federation.

Namely, the Energy and Petrochemical cluster of the cluster, which have significant differences on defined above criteria. 
Energy cluster presents a power Generating company Network company Dispatch center and group repair and manufacturing industries. The feature of this cluster is the local market for heat and electricity, the main consumers are located within the region.

Petrochemical cluster includes a group of enterprises, including Nizhnekamskneftekhim, Kazanorgsintez, TANECO. Feature is the high share of exports. Two clusters operate in different competitive environment. This is also different pricing models - the price of the products of the petrochemical cluster is formed in market conditions, taking into account market conditions.

The energy complex is characterized tariff pricing in terms of actual monopoly.

\section{Result}

Today, the power of the Tatarstan Republic is as follows. Cluster-forming enterprises are involved in the generation of electricity. Around generation formed a powerful cluster of enterprises - manufacturers of power equipment, a cluster of companies that provide services in the delivery of energy to consumers, such as JSC "Grid company", heat network company, energy service and engineering companies, research and educational centers.

The study of the dynamics of sales and financial results, was the dependence of the industry on tariff policy, and, as a consequence, the ability to control the processes of formation of financial resources by non-market pricing. This fact has a powerful impact on the investment activity of enterprises of this group and interaction with the financial market.

In table 1 presents data on the structure of financing sources of investments into the fixed capital of the enterprises of the group.

Immediately draws attention to the fact that the major and in General the dominant source of are own funds of the enterprises of the group. It is interesting to see the change in this share over time during the reporting period. She fell from $82,4 \%$ in 2005 to $76,2 \%$ in 2006 , which is explained by the reduction in profits due to low growth rates. This year $17.6 \%$ financing of the investment program of enterprises was carried out at the expense of the Tatarstan Republica's budget.

Table 1. Structure of investments in fixed capital by sources of financing (production and distribution of electricity, gas and water)

\begin{tabular}{|c|c|c|c|c|c|c|}
\hline \multirow{2}{*}{ Year } & \multirow{2}{*}{ Investments, total (\%) } & \multirow{2}{*}{ Own funds (\%) } & \multirow{2}{*}{ Total } & \multicolumn{3}{|c|}{ of these budgetary funds } \\
\cline { 5 - 7 } & & & & total & \multicolumn{2}{|c|}{ including means } \\
\cline { 5 - 7 } & & & & & Federal & Regional \\
\hline 2005 & 100 & 82,4 & 17,6 & 14,8 & 9,7 & 4,5 \\
\hline 2006 & 100 & 76,2 & 23,8 & 19,4 & 1,7 & 17,6 \\
\hline 2007 & 100 & 85,4 & 14,6 & 4,4 & 1,8 & 2,0 \\
\hline 2008 & 100 & 62,8 & 37,2 & 4,4 & 1,7 & 1,6 \\
\hline 2009 & 100 & 92,5 & 7,5 & 0,4 & 0,3 & - \\
\hline
\end{tabular}

Comparing these data are presented in table 2 the data for the entire industry of Tatarstan, there was clear difference in the trends and nature of interactions of real and financial sectors. In 2009, more than $60 \%$ of all investments in the industry of the Republic of Tatarstan was carried out at the expense of borrowed funds.

Table 2. Structure of investments in fixed capital by sources of Finance (all industries)

\begin{tabular}{|c|c|c|c|c|c|c|}
\hline \multirow{2}{*}{ Year } & \multirow{3}{*}{ Investments, total (\%) } & \multirow{3}{*}{ Own funds (\%) } & \multirow{3}{*}{ Total } & \multicolumn{3}{|c|}{ of these budgetary funds } \\
\cline { 4 - 7 } & & & & total & \multicolumn{2}{|c|}{ including means } \\
\cline { 5 - 7 } & & & & & Federal & Regional \\
\hline 2005 & 100 & 72,4 & 25,8 & 2,2 & 1,5 & - \\
\hline 2006 & 100 & 60,7 & 39,3 & 1,9 & 0,4 & 1,4 \\
\hline 2007 & 100 & 61,5 & 38,5 & - & - & - \\
\hline 2008 & 100 & 52,5 & 47,5 & 0,5 & 0,2 & - \\
\hline 2009 & 100 & 39,3 & 60,7 & 0,5 & 0,5 & - \\
\hline
\end{tabular}


However, despite the fact that enterprises of energy practically does not use the potential of the financial market to raise funds for implementation of investment programs, the level of their investment activity higher than for industry as a whole.

The refresh rate is at 15\% per year, while the degree of wear of fixed assets in the energy sector is lower than for industry as a whole.

The coefficient update $=($ Capital expenditures for the year $/$ The value of fixed assets at beginning of year $) \times 100 \%$

Petrochemical cluster presents dozens of companies, most large strategic enterprises of the Republic of Tatarstan are concentrated in the ownership of JSC "Tatneftekhiminvest-holding".

Below is the evaluation of the interaction of the largest enterprises of Petrochemical cluster in Tatarstan Republic with the financial sector in two main aspects: in conjunction with the banking system and in relationship with the stock market.

Connection with the credit and banking system is reflected in table 3 the credit history companies on the basis of interaction with commercial banks on the basis of data from financial statements of companies in 2005-2009.

Table 3. Credit history of the largest enterprises of Petrochemical cluster in Tatarstan Republic

\begin{tabular}{|l|c|c|c|c|}
\hline The name of the borrower & $\begin{array}{c}\text { The average loan } \\
\text { term, years }\end{array}$ & $\begin{array}{c}\text { The average } \\
\text { loan amount, } \\
\text { million USD }\end{array}$ & $\begin{array}{c}\text { The number of } \\
\text { borrowings }\end{array}$ & $\begin{array}{c}\text { Occurred } \\
\text { arrears }\end{array}$ \\
\hline JSC «Nizhnekamskneftekhim» & 7,4 & 95,8 & 8 & no \\
\hline JSC «Nizhnekamskshina» & 0,6 & 2,9 & 12 & no \\
\hline JSC «Chemical plant named L.Y. Karpov» & 3,5 & 3,8 & 2 & no \\
\hline JSC «KazanorgsinteZ» & 6,7 & 1877 & 14 & yes \\
\hline JSC «Nefis CosmeticS» & no data & 2,3 & more than 60 & no \\
\hline JSC «Tatneft» & 4 & 2100 & 3 & no \\
\hline
\end{tabular}

You can mark the active cooperation of the largest enterprises of Petrochemical cluster in Tatarstan Republic with the credit and banking system, and the degree of this interaction in most of the surveyed enterprises in the dynamics increases, which manifests itself in increasing amounts and types of loans. But the availability of loans from most of the enterprises of Petrochemical cluster in Tatarstan Republic, comparable with the volume of attracted credits, indicates non-market mechanisms for attracting financial resources in Tatarstan Republic's petrochemical cluster, which is a negative factor, because it does not contribute to the development of relations between the financial sector with industrial.

\section{Conclusion}

1. The study group of energy companies characterized by a high level of efficiency, ROI is above the average for the industry and the economy as a whole.

The reason the current system of tariff regulation, when all expenses are covered by the growth of tariffs, i.e. have to be paid by end consumers.

In such circumstances, the group's companies receive a significant profit, which is invested in the production. The investment process is intensive. The main source of investment it is equity - accumulated profit and depreciation of the company.

It can be assumed that with a projected shortage of domestic resources for the implementation of industrial investment, turn on mechanism of lobbying, which ultimately affects the adjustment of tariffs.

2. We found the dependence of the real economy and financial institutions on the characteristics of territorialindustrial cluster. The main parameters that characterize a particular type of cluster, and determining the orientation and activity of the integration processes with the institutions of the financial sector, the following:

- orientation of trade relations in foreign markets or the predominance of a larger share of sales within the region;

- vertical or horizontal linkages of enterprises within the cluster and the presence among these enterprises local monopoly;

- $\quad$ the nature of competition and pricing for the products.

On the basis of these parameters on the territory of the Republic of Tatarstan was revealed two main clusters, different relationship with financial institutions: power and petrochemical. In the energy sector pricing tariff and regulated 
by the state. The petrochemical sector are more closely related to financial institutions and active use of modern financial instruments.

\section{References}

Allen F., Santomero A. The Theory of Financial Intermediation // Journal of Banking and Finance.1997.Vol. 21. pp. 1461-1485.

Cervena M. The Measurement of Capital Flight and Its Impact on Long-Term Economic Growth: Emperical Evidenence from a CrossSection of Countries. Bratislava, 2006

Safiullin L.N., Shaidullin R.N., Ulesov D.N., Shigabieva A.M. Essential features of small and medium business. Life Science Journal 2014; 11(6s): $392-395$.

Askhatova, L.I., Bulnina, I.S. Quality-of-life (QOL) improvement as a strategic resource of sustainable social and economic development of a region. Life Science Journal, Volume 11, Issue 6 SPEC. ISSUE, 2014, Pages 354-35.

Eichengreen B., Rose A. Staying afloat when the wind shifts: External factors and emerging-market banking crises, NBER Working paper 6370, 1998.

Narmania D., Banking Risk Management Features in the Post-Crises Period, Economics and Business \#3, 2011.

Kundukchyan R.M., Gaizatullin R.R., Zappartova Z.N., Antonova N.V. Performance Evaluation of Institutional Integration Forms in Real and Financial Sector Companies, Mediterranean Journal of Social Sciences, 2014, Vol.5. No 12. pp. 59-62.

Cornett M., Tehranian H., Changes in Corporate Performance Associated with Bank Acquisitions", Journal of Financial Economics, 1992, Vol. 31, pp. 211-234.

Bulnina, I.S., Askhatova, L.I. Propositions and suggestions addressed to implement the provisions of the Russian federal law No 217. Mediterranean Journal of Social Sciences, Volume 5, Issue 18 SPEC. ISSUE, 2014, Pages 129-132

Diamond D.W., Dybvig P.H. Bank Runs, Deposit Insurance, and Liquidity // Journal of Political Economy. 1983. Vol. 91. № 3. pp. 401_ 419.

Bergman E.M., Feser, E.J. Industrial and Regional Clusters: Concepts and Comparative Applications. Virginia: WVU Regional Research Institute, 1999

Porter M.E. On Competition. Boston: Harvard Business Review Book, 1998

Solvel O., Lindqvist G., Ketels CH. The Cluster Initiatives Greenbook. 2006.

Shaidullin R.N., Ulesov D.V., Shigabieva A.M. and Safiullin L.N. Innovative Infrastructure in Post-Industrial Society/l World Applied Sciences Journal, 27(13), 2013, pp. 180-183. 